\title{
The Design of Population Data Application Using Unified Modeling Language
}

\author{
Alim Hardiansyah ${ }^{1}$, Ravie Kurnia Laday ${ }^{2}$, Muhammad Suhaeli ${ }^{3}$ \\ ${ }^{1,2,3}$ Department of Informatic, Institut Sains dan Teknologi Al-Kamal Jakarta, Indonesia \\ alimhardiansyah@ista.ac.id, ${ }^{2}$ ravie@ista.ac.id, ${ }^{3}$ hally009@ista.ac.id
}

\begin{abstract}
Population data collection at the sub-district level still uses a manual system. It is causing less efficient time. In this study the application of population data is generated in the sub-district, using web applications and using the Unified Modeling Language design. With the above considerations, we need a system that can solve population data problems. With this application, it is expected that it will facilitate the processing of population data. This new application can accelerate the process of population registration with the help of human resources who can run it. Advice needed human resources that can run the application properly.
\end{abstract}

Keywords: Population data application, Unified Modeling Language

\section{INTRODUCTION}

Residents are part of a country. In Indonesia, the population consists of various kinds of customs and cultures which are certainly not small in number. The amount is not always the same every year, to know the change in population, then population registration is carried out, in Indonesia every five years, also called the population census. Data acquisition through the population census is still aggregate.

Therefore it is necessary to carry out an update on population data collection. Population data collection is the responsibility of the district/city government, where the implementation starts from the village / kelurahan as the spearhead of population data collection. In this service, it needs to be done correctly and quickly so that the residents as customers feel that they have satisfactory service.

Application of population data is intended to improve efficiency in terms of community service and population development, currently, population data is still in the form of manual so that it slows down the process of adding, changing and eliminating and other population data collection processes. The application is in the form of software that functions to process population data for a particular policy.

The purpose of this study is to make Population Data Applications so as to produce accurate and accurate population data reports, in order to help resolve problems regarding the processing of population data.

The application is made to serve the process of making ID cards, making KK, making birth certificates, making death certificates, making resettlement letters, SKCK cover letters, building permits, and small and medium-sized business permits. Bring up output in the form of birth diagrams, death diagrams, population mutation diagrams.

\section{METHOD}

The overview of the method that implemented in this work describe on the following figure:

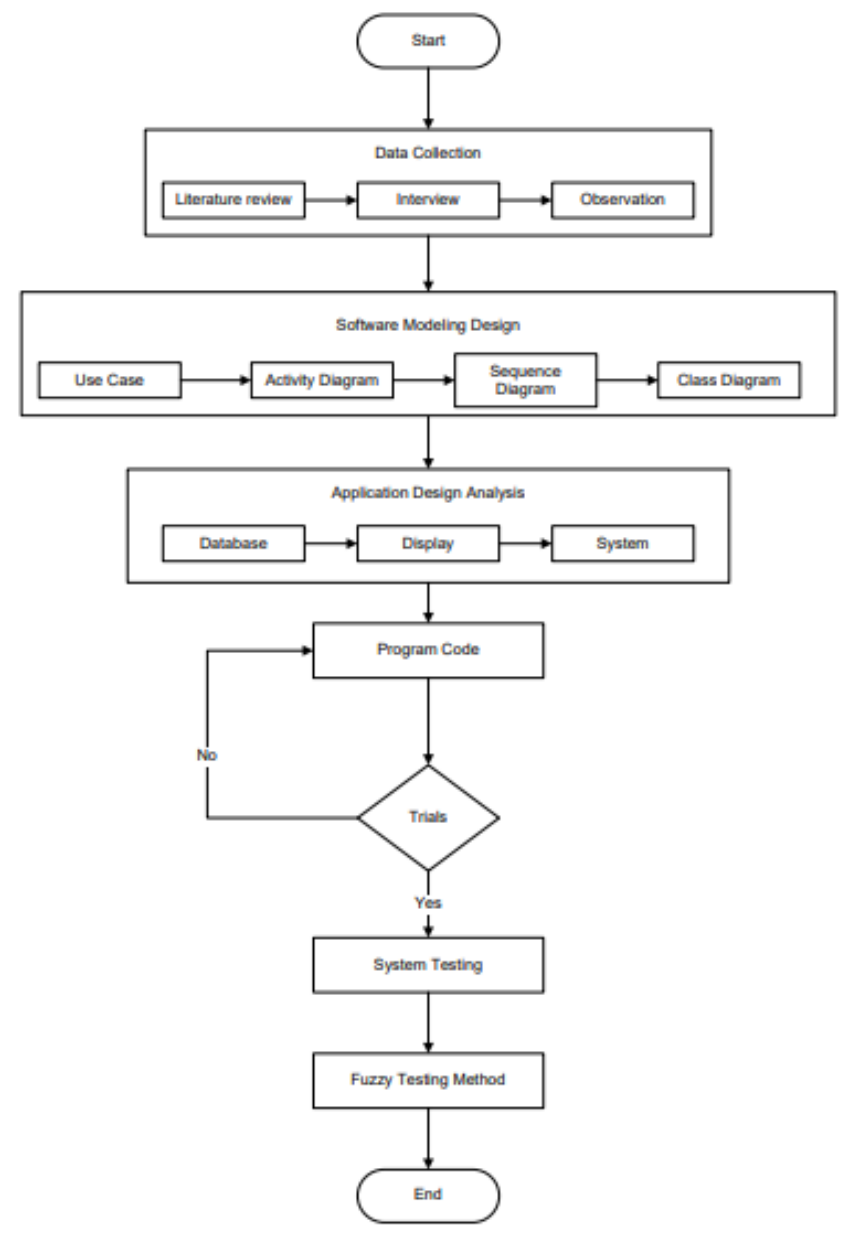

Figure 1. Flowchart 
The field orientation of this research was at the Talang District Office, Tegal Regency, Central Java. the problem is the processing of population data in Talang District.

Library studies are conducted to retrieve some of the literature related to the material, Interview (interview), Conduct interviews or provide questions that aim to collect data to related parties such as lurah, sub-district head, and head of population, observation, In this case the author does field survey to find out how to record the availability of files and data collection of incoming and outgoing files. In the system design process, UML (Unified Modeling Language) uses object-oriented system development technology [1]-[4].

Source code allows programmers to communicate with computers using several defined commands. Source Code is a program that is usually made in one or more text files, sometimes stored in databases that are stored as procedures and can also appear as code snippets printed in books or other media. The large collection of source code files can be arranged in a tree directory, in this case, it might also be known as Source Tree.

Tests and program evaluations that have been made. If the program that is made does not find errors, the program has been fixed and the implementation of the program is carried out. If you find a fatal error in the program, a re-coding is done for improvement on the program that has been made.

XAMPP with a complete package consisting of Apache / 2.4.23 OpenSSL / 1.0.2h PHP / 5.6.24. This computer software has the advantage of being able to act as the Apache web server for website development simulations [5]. This web development tool supports popular web technologies such as PHP, MySQL, and Perl. MySQL and PHP commonly used on the small, middle, and large software development project [6][7][8][9][10][11]. Previous research, PHP implement as a multi-tier integration and got a good performance [12][13]. Further work this database engine very possible to elevate on the OLAP system [14].

Testing this program uses the black box method. Black box testing is a test that is performed only by observing the results of execution through test data and functional checking of software. So analogous to how we see a black cat, the kit can only see its outer appearance, without knowing what is behind the black wrapper. Just like black box testing, evaluating only from its external appearance, its functionality. without knowing what happened in the detailed process (only knowing the input and output).

\section{RESULT AND DISCUSSION}

\section{A. System Analysis}

System analysis aims to identify problems problems that exist in the system where the application is built which includes hardware (software) and software (users). This analysis is needed as a basis for the stages of system design. System analysis includes problem identification, application specifications, user specifications, and operating environment.

\section{B. System Requirement}

Before building a system, activities to identify needs must be carried out. It is intended that the system developed can work in accordance with the goals and needs of the wearer. The system needed as follow:

1. The system must be able to provide information to the public relating to the population administration process.

2. The system can input population data in accordance with the choice of available features.

3. The authorized officer must be able to access the system online.

4. The system must be able to provide facilities for changing registration data.

Results of print out various documents such as KTP, $\mathrm{KK}$, deed, etc. only can be taken from the relevant agency.

\section{Process Flow}

The description of the system flow that is currently running in Talang District for the Making of Birth Certificates can be seen from the flowchart diagram in Figure 2.

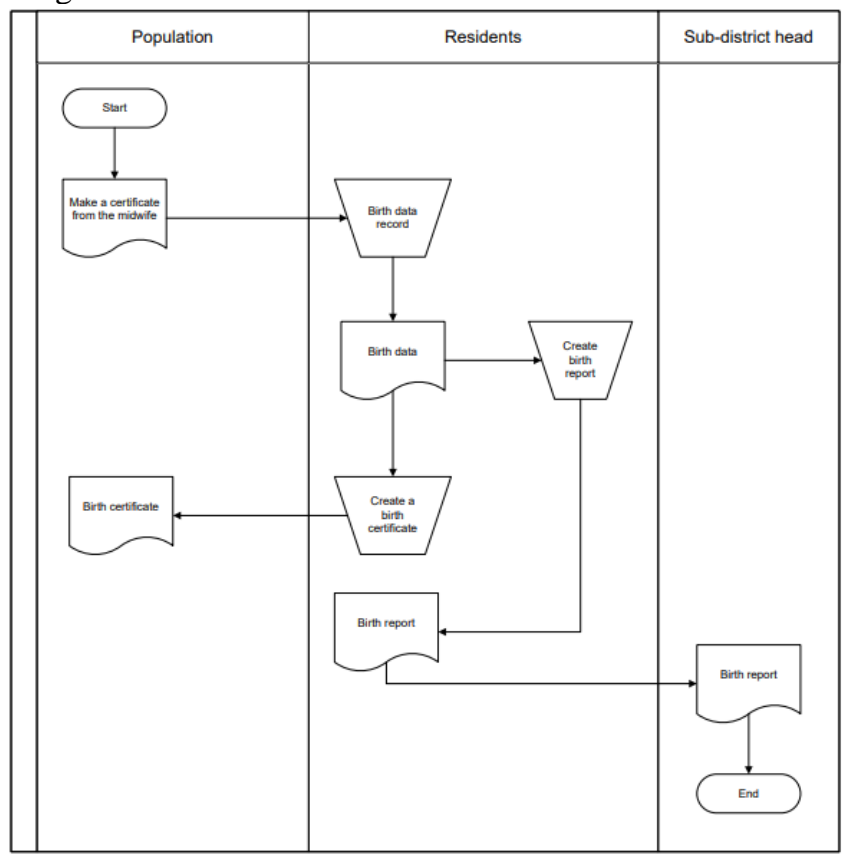

Figure 2. Flowchart of the System Flow Running Birth

$$
\text { Certificate }
$$

The following is an explanation of the system flowchart diagram that runs in Talang District in making Birth Certificates: residents fill in the birth certificate form, Population records record birth data and then make birth reports, and after that the population will make a birth certificate statement. Then, the birth certificate statement is then given to the sub-district. 


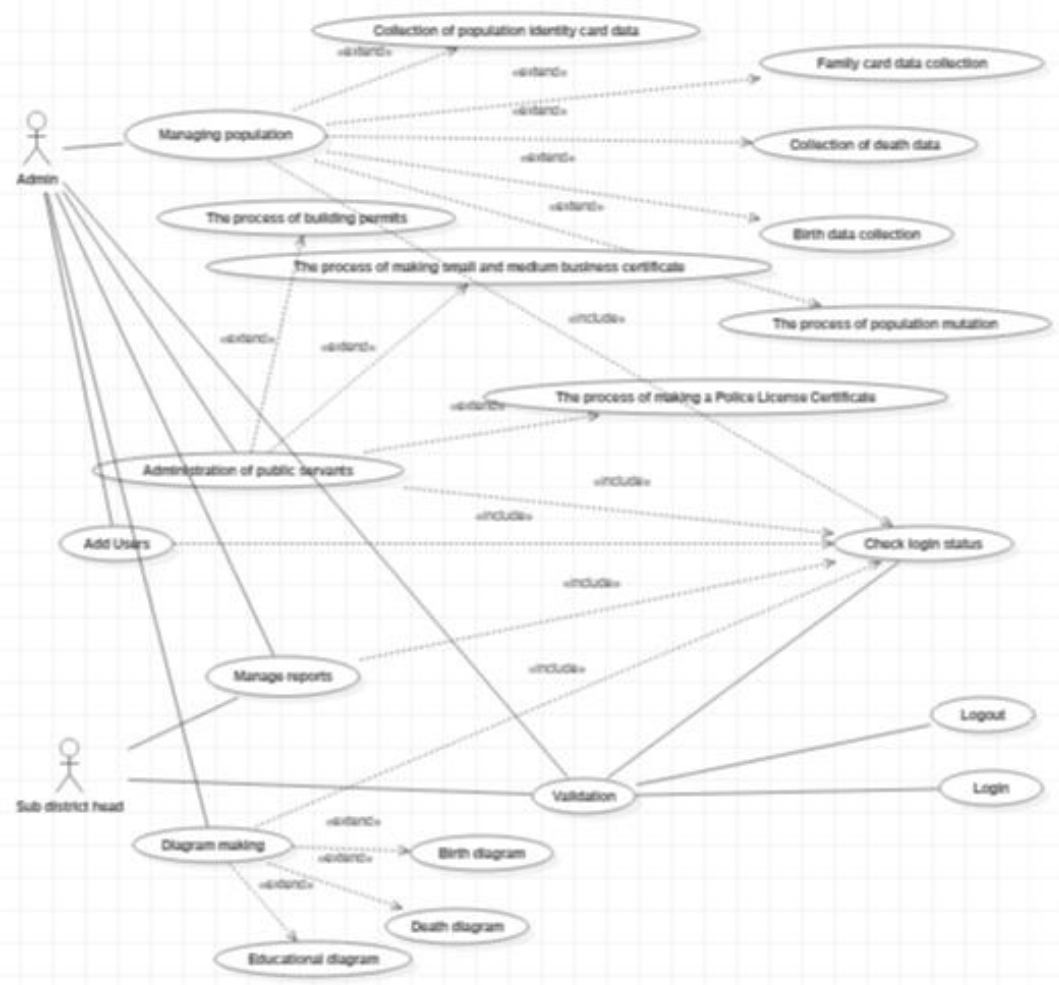

Figure 3. Use Case Diagram

\section{Use Case Diagram}

Use case diagram describes the interaction between actors and systems. For population data applications, it has 2 (two) actors, namely the Admin section whose task is to enter data relating to population and the Camat, namely the sub-district leader as a district or city. Use Case diagram can be seen in figure 3 .

\section{E. Activity Diagram}

Login process used by admin functions to update data consisting of several home submenus, KTP data collection, family card data collection, birth data, death data collection, SKCK cover letter, IMB data, UKM permit letter, user add, and manage reports. The following is an illustration that will be explained in the activity diagram of Figure 4.

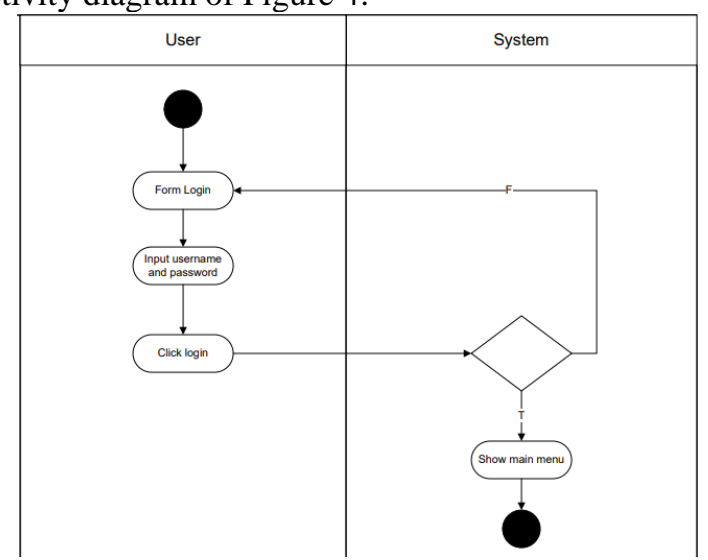

Figure 4. Activity Diagram Login
KTP Data Collection Flow is used by admin to edit, add, delete and print KTP data. The following is an illustration that will be explained in the population data activity diagram in figure 5 .

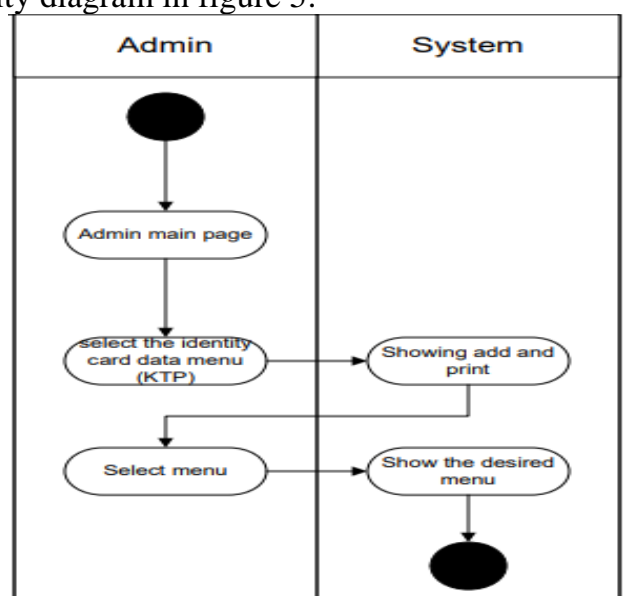

Figure 5. Activity Diagram Data KTP

\section{F. Class Diagram}

Class diagrams are diagrams that show relationships between classes in which there are attributes and functions of an object. The following is an overview of the class diagram for the Population Information Administration System in Talang District, shown in the additional suplementary files. 


\section{G. Sequence Diagram}

The KTP data collection process begins with adding KTP data, besides adding the system, it can also edit data, and delete existing data. This process is done when the admin and the camatt have logged in first, then the admin can add KTP data, edit or delete, before the process is saved to the system database, it will validate first, whether the inputted data is correct or incorrect.

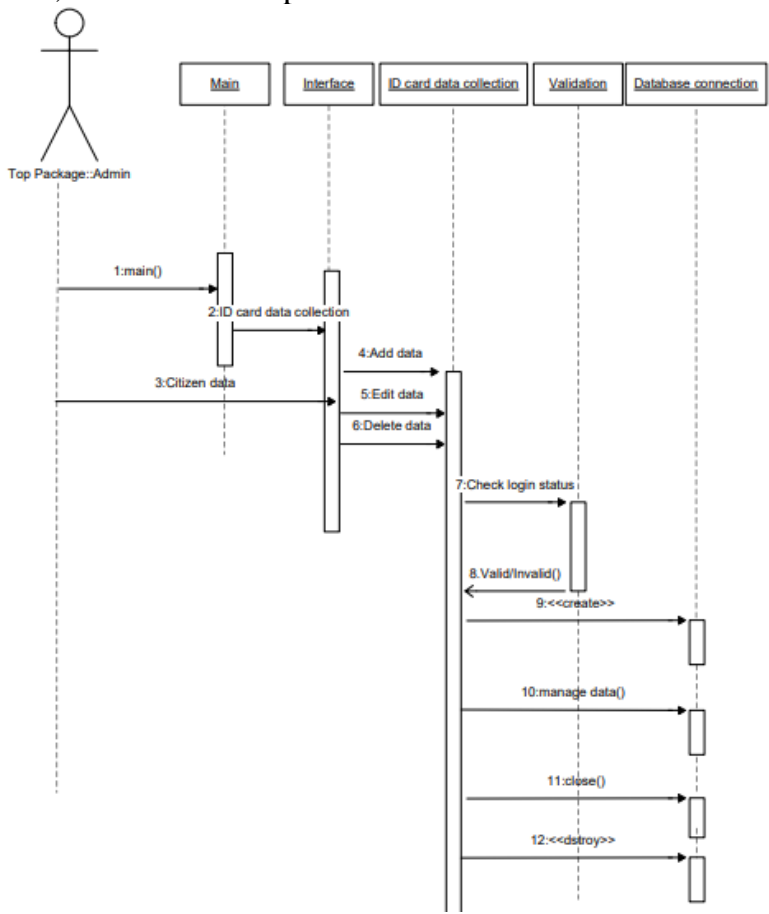

Figure 6. Sequence Diagram Collecting data KTP

\section{H. Graphical User Interface}

The design of the display is a display of the population data collection application to be built. The following picture is the display of the Population Data collection application that the author made. Consists of a list page and a login page.

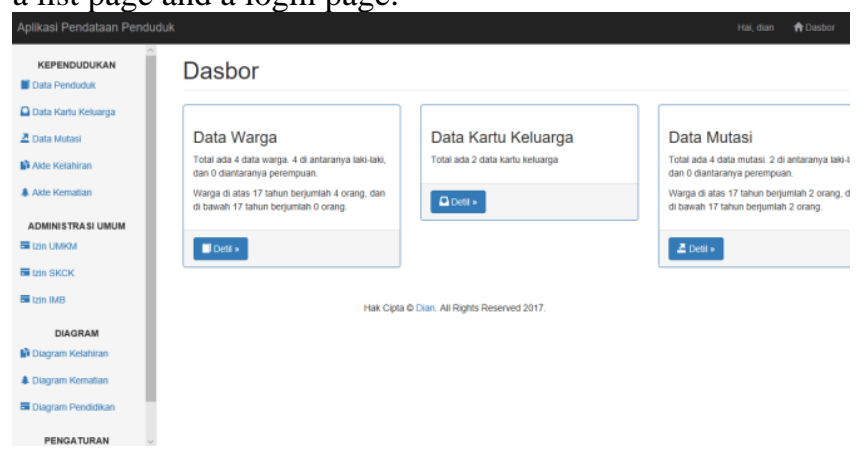

Figure 7. GUI of Main Menu

The user can access population module that describe on the following figure:

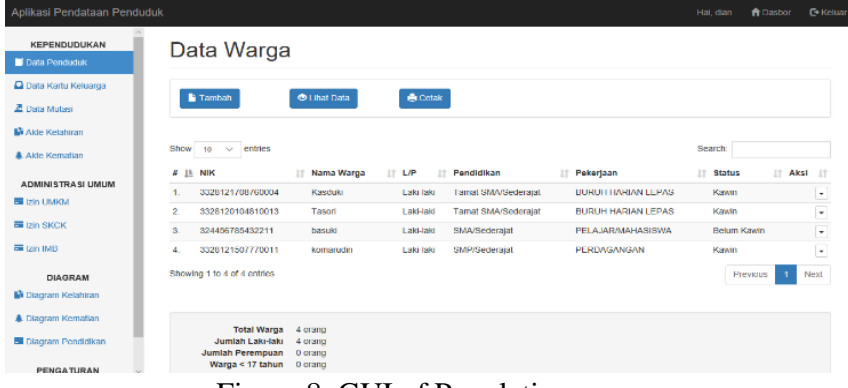

Figure 8. GUI of Population

This application shows birth data including statistic information using several diagrams. For example birth data on figure 11 .

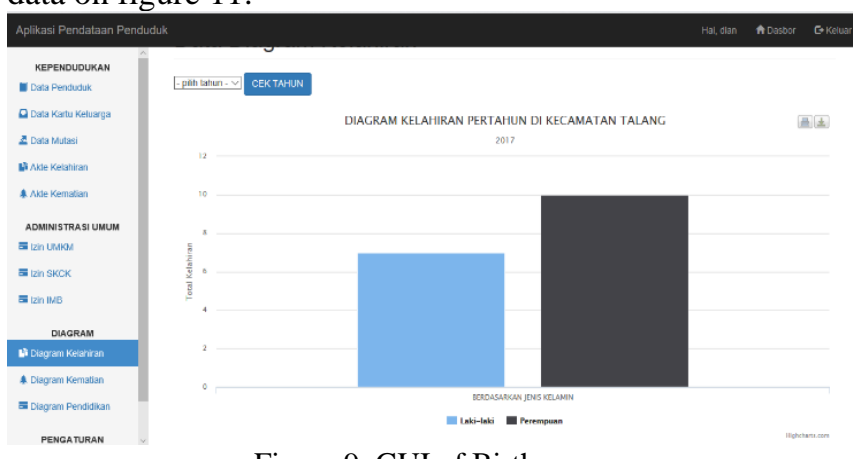

Figure 9. GUI of Birth

\section{Alpha Test}

On the testing phase, we try to find out whether the system created is in accordance with the expected and has met the functional requirements of the system work procedures or not. Further information about test phase explain on the following table:

Table 1. Scenario of Alpha Test

\begin{tabular}{|c|c|c|c|}
\hline No & Component & Test Item & $\begin{array}{l}\text { Type of } \\
\text { Testing } \\
\end{array}$ \\
\hline \multirow[t]{2}{*}{1} & \multirow[t]{2}{*}{ Login Admin } & $\begin{array}{l}\text { Verify admin login } \\
\text { data by entering } \\
\text { username and } \\
\text { password }\end{array}$ & Black-box \\
\hline & & $\begin{array}{l}\text { Login data error } \\
\text { information }\end{array}$ & Black-box \\
\hline \multirow{4}{*}{2} & \multirow{4}{*}{$\begin{array}{l}\text { Citizen data } \\
\text { management }\end{array}$} & $\begin{array}{l}\text { Add resident data by } \\
\text { admin }\end{array}$ & Black-box \\
\hline & & $\begin{array}{l}\text { Edit population data } \\
\text { carried out by the } \\
\text { admin }\end{array}$ & Black-box \\
\hline & & $\begin{array}{l}\text { Delete resident data } \\
\text { by admin }\end{array}$ & Black-box \\
\hline & & $\begin{array}{l}\text { Print population data } \\
\text { carried out by admin } \\
\text { and sub-district head }\end{array}$ & Black-box \\
\hline \multirow{4}{*}{3} & \multirow{4}{*}{$\begin{array}{c}\text { Family card data } \\
\text { management }\end{array}$} & $\begin{array}{l}\text { Add family card } \\
\text { data by admin }\end{array}$ & Black-box \\
\hline & & $\begin{array}{l}\text { Edit family card data } \\
\text { by admin }\end{array}$ & Black-box \\
\hline & & $\begin{array}{l}\text { Delete family card } \\
\text { data by admin }\end{array}$ & Black-box \\
\hline & & $\begin{array}{l}\text { Print family card } \\
\text { data by admin and } \\
\text { sub-district head }\end{array}$ & Black-box \\
\hline
\end{tabular}




\begin{tabular}{llll}
\hline & $\begin{array}{c}\text { Management of } \\
\text { population } \\
\text { mutation data }\end{array}$ & $\begin{array}{l}\text { Edit population } \\
\text { mutation is done by } \\
\text { admin }\end{array}$ & Black-box \\
\cline { 3 - 3 } & $\begin{array}{l}\text { Delete population } \\
\text { mutation data by } \\
\text { admin }\end{array}$ & Black-box \\
\hline
\end{tabular}

This test aims to show whether the function of the software runs well as desired. Testing is done by trying all the possibilities that have occurred and testing is done repeatedly.

Table 2. Alpha Testing

\begin{tabular}{|c|c|c|c|}
\hline Case tested & $\begin{array}{c}\text { Test } \\
\text { scenario }\end{array}$ & $\begin{array}{c}\text { Expected } \\
\text { results }\end{array}$ & Test result \\
\hline \multirow[t]{2}{*}{$\begin{array}{l}\text { Testing the } \\
\text { login form }\end{array}$} & $\begin{array}{l}\text { Entering } \\
\text { username } \\
\text { and } \\
\text { password } \\
\text { RIGHT }\end{array}$ & $\begin{array}{l}\text { When data is } \\
\text { entered and } \\
\text { the login } \\
\text { button is } \\
\text { clicked, the } \\
\text { data checking } \\
\text { process will be } \\
\text { carried out. If } \\
\text { true, it will go } \\
\text { directly to the } \\
\text { admin main } \\
\text { page. }\end{array}$ & $\begin{array}{l}\text { [x]Accepted } \\
{[] \text { Rejected }}\end{array}$ \\
\hline & $\begin{array}{l}\text { Enter your } \\
\text { username } \\
\text { and } \\
\text { password } \\
\text { data } \\
\text { FALSE }\end{array}$ & $\begin{array}{l}\text { When data is } \\
\text { entered and } \\
\text { the login } \\
\text { button is } \\
\text { clicked, the } \\
\text { data checking } \\
\text { process will be } \\
\text { carried out. If } \\
\text { the data is } \\
\text { wrong, the } \\
\text { system will } \\
\text { display a } \\
\text { failed login } \\
\text { message and } \\
\text { return to the } \\
\text { login menu. }\end{array}$ & $\begin{array}{l}\text { [x]Accepted } \\
{[] \text { Rejected }}\end{array}$ \\
\hline \multirow[t]{3}{*}{$\begin{array}{l}\text { Processing } \\
\text { population } \\
\text { data }\end{array}$} & $\begin{array}{l}\text { Add } \\
\text { population } \\
\text { data }\end{array}$ & $\begin{array}{l}\text { When entering } \\
\text { population } \\
\text { data then click } \\
\text { save, then the } \\
\text { data checking } \\
\text { process will be } \\
\text { carried out and } \\
\text { stored in the } \\
\text { database. }\end{array}$ & $\begin{array}{l}\text { [x]Accepted } \\
{[] \text { Rejected }}\end{array}$ \\
\hline & $\begin{array}{l}\text { Edit } \\
\text { population } \\
\text { data }\end{array}$ & $\begin{array}{l}\text { When the } \\
\text { action button } \\
\text { is clicked then } \\
\text { select edit then } \\
\text { the system will } \\
\text { display the } \\
\text { edit data form, } \\
\text { after editing } \\
\text { then clicking } \\
\text { save, the data } \\
\text { will be stored } \\
\text { in the } \\
\text { database. }\end{array}$ & $\begin{array}{l}\text { [x]Accepted } \\
\text { [ ] Rejected }\end{array}$ \\
\hline & $\begin{array}{l}\text { Delete } \\
\text { population } \\
\text { data }\end{array}$ & $\begin{array}{l}\text { When the } \\
\text { action button } \\
\text { is clicked then } \\
\text { select delete, } \\
\text { then the } \\
\text { system will } \\
\text { display a }\end{array}$ & $\begin{array}{l}\text { [x]Accepted } \\
{[\text { ] Rejected }}\end{array}$ \\
\hline
\end{tabular}

\begin{tabular}{|c|c|c|c|}
\hline & & \multicolumn{2}{|l|}{$\begin{array}{l}\text { confirmation } \\
\text { message, if } \\
\text { yes, then the } \\
\text { data will be } \\
\text { deleted. }\end{array}$} \\
\hline & $\begin{array}{l}\text { Print } \\
\text { population } \\
\text { data }\end{array}$ & $\begin{array}{l}\text { When the print } \\
\text { button is } \\
\text { clicked, the } \\
\text { system prints } \\
\text { population } \\
\text { data. }\end{array}$ & $\begin{array}{l}\text { [x]Accepted } \\
\text { [] Rejected }\end{array}$ \\
\hline \multirow[t]{3}{*}{$\begin{array}{l}\text { Processing } \\
\text { family card } \\
\text { data }\end{array}$} & $\begin{array}{l}\text { Add family } \\
\text { card data }\end{array}$ & $\begin{array}{l}\text { When } \\
\text { inputting the } \\
\text { family card } \\
\text { data then click } \\
\text { save, then the } \\
\text { data checking } \\
\text { process will be } \\
\text { carried out and } \\
\text { stored in the } \\
\text { database. }\end{array}$ & $\begin{array}{l}\text { [x]Accepted } \\
{[\text { ] Rejected }}\end{array}$ \\
\hline & $\begin{array}{l}\text { Edit family } \\
\text { card data }\end{array}$ & $\begin{array}{l}\text { When the } \\
\text { action button } \\
\text { is clicked then } \\
\text { select edit then } \\
\text { the system will } \\
\text { display the } \\
\text { edit data form, } \\
\text { after editing } \\
\text { then clicking } \\
\text { save, the data } \\
\text { will be stored } \\
\text { in the } \\
\text { database. }\end{array}$ & $\begin{array}{l}\text { [x]Accepted } \\
\text { [] Rejected }\end{array}$ \\
\hline & $\begin{array}{l}\text { Delete } \\
\text { family card } \\
\text { data }\end{array}$ & $\begin{array}{l}\text { When the } \\
\text { action button } \\
\text { is clicked then } \\
\text { select delete, } \\
\text { then the } \\
\text { system will } \\
\text { display a } \\
\text { confirmation } \\
\text { message, if } \\
\text { selected, then } \\
\text { the data will } \\
\text { be deleted. }\end{array}$ & $\begin{array}{l}\text { [x]Accepted } \\
\text { [ ] Rejected }\end{array}$ \\
\hline
\end{tabular}

\section{CONCLUSION}

The design of population data applications can provide an overview of the system that will be used in the process of inputting data, managing data, and also viewing reports on population data for each resident. Regarding the construction of this population data application, inputting and searching population data and services becomes faster and more appropriate with the help of human resources who can run it. Data relating to population is stored computerized on the database, so that data is safer should the data be backed up first so that there is a backup of data storage.

In further work, we recommend that the population data application is run online, so that district staff can input and view reports anywhere and anytime. In order for this computerized system to work properly, human resources are needed to run the system properly. Data should be backed up automatically to avoid data loss or viruses. 


\section{REFERENCES}

[1] D. S. Maylawati, W. Darmalaksana, and M. A. Ramdhani, "Systematic Design of Expert System Using Unified Modelling Language," IOP Conf. Ser. Mater. Sci. Eng., vol. 288, no. 1, p. 012047, 2018.

[2] L. Jin and X. Liang, "System Modeling of Vehicle Management Based on RUP and UML," in 2012 Fifth International Symposium on Computational Intelligence and Design, 2012, pp. 53-56.

[3] S. Dharwiyanti and R. S. Wahono, "Pengantar Unified Modeling LAnguage (UML)," IlmuKomputer.com, 2003. [Online]. Available: http://www.unej.ac.id/pdf/yanti-uml.pdf. [Accessed: 02-Aug-2017].

[4] P. P. Widodo and Herlawati, Menggunakan UML (Unified Modelling Language). Bandung: Informatika, 2011.

[5] N. I. Ilham, E. H. M. Saat, N. H. A. Rahman, F. Y. A. Rahman, and N. Kasuan, "Auto-generate scheduling system based on expert system," in 2017 7th IEEE International Conference on Control System, Computing and Engineering (ICCSCE), 2017, pp. 6-10.

[6] W. Yuan, L. Shuhua, and Z. Haifeng, "Design and realization of the LED management system based on PHP," in Proceedings of 2011 International Conference on Electronic \& Mechanical Engineering and Information Technology, 2011, pp. 246-248.

[7] U. Sa'adah, J. Akhmad, and M. Hisyam, "Implementing Singleton method in design of MVC-based PHP framework," in 2015
International Electronics Symposium (IES), 2015, pp. 212-217.

[8] A. Munandar, "Pengertian MySQL," 2016. .

[9] "Hystory of MySQL." [Online]. Available: http://dev.mysql.com/doc/refman/5.0/en/history.html. [Accessed: 02-Aug-2017].

[10]I. Heryanto, B. Raharjo, and E. R.K., Modul Pemrograman Web (HTML, PHP \& MySql). Bandung: Modula, 2010.

[11] N. F. Naim, A. I. M. Yassin, W. M. A. W. Zamri, and S. S. Sarnin "MySQL Database for Storage of Fingerprint Data," in 2011 UkSim 13th International Conference on Computer Modelling and Simulation, 2011, pp. 293-298.

[12] R. Szklarczyk, "GNU Prolog-PHP multi-tier integration," in 2013 IEEE 7th International Conference on Intelligent Data Acquisition and Advanced Computing Systems (IDAACS), 2013, pp. 338-341.

[13] K. Bounnady, K. Phanthavong, S. Pathoumvanh, and K. Sihalath, "Comparison the processing speed between PHP and ASP.NET," in 2016 13th International Conference on Electrical Engineering/Electronics, Computer, Telecommunications and Information Technology (ECTI-CON), 2016, pp. 1-5.

[14] N. Anggraini, N. F. Rozy, and R. M. Putra, "Implementation of OLAP (On-Line Analytical Processing) on car parts sale of Mercedes Benz (Case study: PT. Mass Sarana Motorama)," in 2014 International Conference on Cyber and IT Service Management (CITSM), 2014, pp. 1-4. 